\title{
The Impact of Digital Marketing on Consumer Buying Decision Process in the Egyptian Market
}

\author{
Amira M. Omar ${ }^{1} \&$ Nermine Atteya ${ }^{2}$ \\ ${ }^{1}$ Faculty of Economics and International Trade, Egyptian Chinese University, Cairo, Egypt \\ ${ }^{2}$ School of Business, Madonna University, Michigan, USA \\ Correspondence: Amira M. Omar, Faculty of Economics and International Trade, Egyptian Chinese University, \\ Cairo, Egypt. E-mail: aomar@ecu.edu.eg, amirazeinaone@hotmail.com
}

Received: February 25, 2020

doi:10.5539/ijbm.v15n7p120
Accepted: May 28, 2020

Online Published: June 8, 2020

\begin{abstract}
This research examines digital marketing channels (E-mail Marketing, Mobile Marketing, and Retargeting) for marketers. It analyzes the effect of these channels on the consumer buying decision process in the Egyptian market.

The author researched an online questionnaire. The questionnaires were administered based on a simple sampling method and obtained in the Egyptian market. 285 questionnaires were distributed, and 213 available samples were collected, except incomplete questionnaires, resulted in a response rate of $74.7 \%$ to all those who chose to participate. Findings indicate that e-mail has a profoundly positive influence on consumer buying decisions in two phases (post-purchase) and information research). In the purchase, the decision phase has a negative effect on customer decisions. The mobile, as a digital marketing channel, has a negative impact on consumer decisions through all the stages of the consumer buying decision process in the Egyptian market. Also, re-targeting has a high effect on consumer decisions in the evaluation stage; then, information research needs recognition, purchase decision, and post-purchase.

Targeting is the most influential variable in the consumer buying decision process. We can notice that the most significant effect on the consumer decision is in the evaluation stage, and this can be due to that the re-targeting channel directed to the consumer who has already been searching for the product.
\end{abstract}

Keywords: E-mail marketing, mobile marketing, retargeting, digital marketing, and consumer buying decision process

\section{Introduction}

Technology evolution made our world dynamic quicker than it has ever been before. The influence on business, and especially marketing techniques, has been significant. Trends are dynamic from ancient techniques of marketing to new approaches wherever the digital channels currently play a vital role. Also, a considerable shift from outbound marketing strategies to inbound marketing methods has taken place. Digital marketing was seen as a revolutionary form of marketing that offered businesses new ideas to try to do business. Marketing activities carried out through digital channels enabled marketers to communicate directly with potential customers regardless of their geographic location. Understanding the way to use digital channels has exaggerated, just like the web, e-mail, mobile phones, and digital T.V. in promoting, and marketers are currently using these channels for various functions. For instance, some use them for getting new customers, whereas some specialize in serving customers higher. Digital marketing communication has generally been information regarding merchandise, advertising on the online, and marketing via e-mail and mobile. It seems like the channels and ideas of digital marketing are used individually and operationally, whereas recognizing the effect of various digital channels on customer buying decisions is still developing. E-mail continues to be a good marketing strategy. E-mail creates \$38 for each \$1 spent, and this is an astonishing 3,800\% ROI, making it one in all the furthermost effective selections available. Predictably, Active e-mail accounts are to hit 5.6 billion in 2019 (Statista, 2018). It's assessed that the U.S. will outlay more than 350 million dollars on e-mail marketing in 2019 (Statista, 2019). Over $50 \%$ of U.S. respondents check their private e-mail account relatively ten times every day, and it's without a doubt, their furthermost popular way to receive updates from brands (Campaign Monitor, 2017). $99 \%$ of customers check their e-mail every day. (DMA Insights, 2017) 
Increasing sales prediction, and acquiring more consumers, will be the most critical priorities for marketing influencers (64\% and 55\% respectively) in 2019, this asserts the significance of marketing support of and placement with the sales process. (Digital Marketing Strategies Survey by Ascend2,2019). Figur1 represents the top priorities for the digital marketing strategy to achieve.

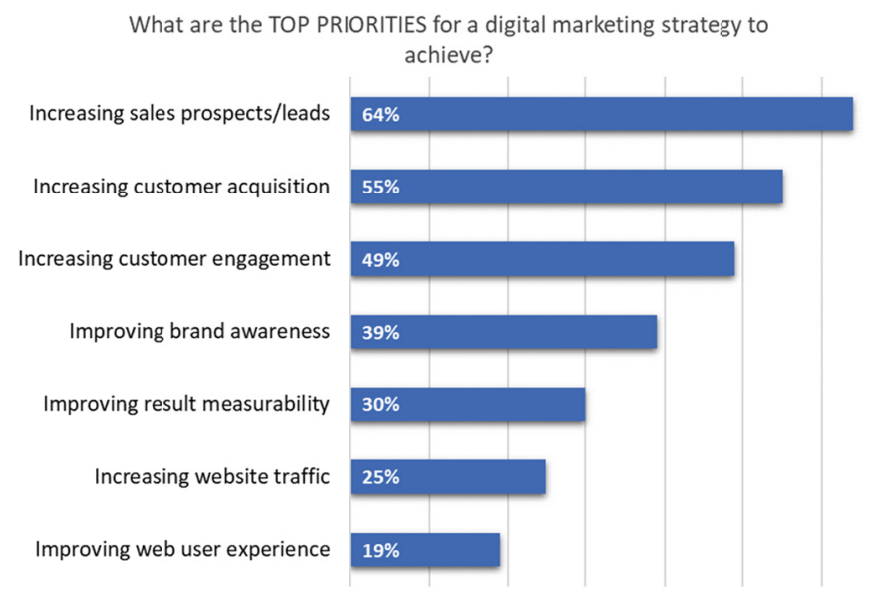

Figure 1. The top priorities for a digital marketing strategy to achieve (2019 Digital Marketing Strategies Survey by Ascend2)

Once buying a commodity, the buyer often goes through five different stages; problem-recognition, information search, alternative evaluation, purchase decision, and post-purchase behavior. However, it's clear that the shopping for method starts long before the acquisition of the product and determines effects long once. This is often why marketers have to be compelled to study and understanding of all buying process steps.

This paper examines how marketers can use digital Marketing channels (E-mail Marketing, Mobile Marketing, and Retargeting) to affect consumer buying decision process stages.

\section{Literature Review}

\subsection{Digital Marketing}

Various definitions are identified in previous studies with regard to digital marketing. One definition is that its marketing that utilizes electronic devices like personal computers, smartphones, cell phones, and game consoles to involve the stakeholders to be a part of the procedure. Digital Marketing techniques have the power to repetition several marketing communications aspects and ancient media channels and, in therefore doing, they're able to extend the marketing mix. Digital campaigns are specific and are a part of the marketing communication mix. However, the boundaries are blurred since digital technology isn't just how to communicate yet; it's additionally a method of distribution. (Jobber \& Ellis -Chadwick, 2013).

Studies show that online buying not just effecting easy use and pleasure. Additionally, however, there are different factors, such as the appearance of the product, characteristics, and confidence in online marketing. In line with the researchers, e-marketing has started from the nineteenth century; e-marketing involves the delivery of goods and services from the supplier to the consumer via digital media in totally different ways. It surpasses T.V., radio sets, and newspaper advertisements. Net advertisement, along with various American business journals, is faster than traditional advertising. (Howard, 2011). With a spectacular increase in online advertising, the organizations started to spend more on e-marketing as an alternative to the classical one. (Bakshi \& Surender Kumar Gupta, 2015). The concepts of e-marketing have transformed consumers, society, and the business sector into data, social networking, and the education division (Krishnamurthy \& Sin, 2014). Social networking sites have a vast target marketplace and audiences. They mainly get information about products and services promoted through various social networking sites like Twitter, YouTube, and Facebook. (Elisabeta Ioanăs, 2014).

\subsection{E-Mail Marketing}

E-mail marketing is one of the digital marketing techniques initially used, and it involves providing customized or targeted messages to specific individuals at the proper time. With the e-mails, businesses can send e-mails that meet the user's needs (Scharl, Dickinger, \& Murphy, 2005). 
Besides, E-mail marketing is a kind of direct marketing that utilizes e-mail as a means of communication or fund-promoting messages to link the viewers. In its broadest logic, e-mail marketing can be taken into account for every single e-mail sent to a probable or existing customer. Nevertheless, the term is often used to refer to. 1) the transmission of e-mail messages aimed at improving the link with a business person with his or her current or previous clients, promoting customer loyalty and the replication industry. 2) causation E-mails to get new clients or influential current customers to buy something right away. 3) adding advertisements to e-mails sent through various companies to their consumers (Van Boskrik, Overby \&Takvorian, 2011)

E-mail marketing has a lot of advantages like; that you can adjust messages for diverse clients and offer promotions which are steady with their profile ( Jenkins,2009), you can simply measure the quantity of sent E-mail messages, signed E-mails as seen and the figure of people are not registered, E-mail marketing is understood as a marketing authorization, and one of its features is that it allows consumers to decide whether or not they would like to be reached by e-mail. (Davis,2010).

On the other hand, E-mail marketing has some disadvantages as currently, several ISPs utilize complicated junk-mail strainers. Therefore, there's no promise that your E-mails will get into your addressee' inbox. As well, it's possible that addressee deletes association E-mail if they don't know the sender. This can progressively become a shortcoming of e-mail marketing (Fusion, 2011), after an E-mail pass to the consumer, there are such a lot of E-mails that have to be revised. Generally, it is challenging for a person to differentiate between invited and uninvited e-mails, in addition to the time it takes to search via e-mail. One more shortcoming of E-mail marketing is to spread quite a lot of software viruses, and it makes customers distrustful even to the trusty channels and markets (Davis, 2010).

\subsection{Mobile Marketing}

Although mobile phones are commercially on the market for three decades, no one will argue that we have a leaning to utilize these devices now more than ever before. Over the last ten years, the exponential evolution of electronic technology has given us the trend of smartphones, which has not been converted uniquely since we continue to use mobile devices. Still, in the same sense, they give businesses the ability to speak directly with customers, despite the time or space barriers (Haghirian, Madlberger \& Tanuskova, 2005).

Ververidis and Polyzos (2002) described mobile marketing as "all the activities necessary to interact with the consumer through the use of mobile devices to facilitate the selling of products or services and the distribution of information on those products and services." Dickinger, Haghirian, Murphy, and Scharl (2004) describe a different earlier concept, defining mobile marketing as "the use of interactive digital media to provide consumers with time- and location-sensitive, customized information that promotes products, services, and ideas, thereby creating value to all stakeholders." Kaplan (2012) makes the concept simpler by stating that mobile marketing is "any marketing operation carried out through a ubiquitous network to which customers are consistently linked through their personal mobile device." We can notice that all the previous definitions are under the authorized definition, that granted from the umbrella organization of the industry, the Mobile Marketing Association (2009): "Mobile marketing is a set of activities enabling organizations to communicate and engage with their audience members through and with any mobile device or network in an interactive and relevant manner." Technology plays an enormous role in mobile marketing, as soon as the marketing platform includes mobile devices, the appliance itself is not the main marketing element, but the system of specific application technology is regulated to be described as unique marketing tools (Tode, 2013). Marketers have to be compelled to gain additional information regarding mobile technology, particularly concerning different aspects of usability that necessary to customers (Haghirian, etc., 2005). Extraordinary attention has to be placed within the choice of the promotion method to achieve the consideration of the target demographic teams (Zabadi, etc., 2012).

It is vital for corporations to have a diverse marketing strategy that is entirely different from digital marketing. Companies that sell generic goods or services must not focus exclusively on one kind of customer. They have to take into account many targets and embrace their message for every one of them. (García, Lizcano, Ramos \&Matos, 2019)

\subsection{Re-Targeting}

First, we have to explain "recommendation algorithms," which is a very significant feature of re-targeting. Large-scale e-commerce, such as eBay and Amazon, utilizes suggestion algorithms to support the customer in the decision-making process and attract new customers. (Li, Xhang and Wang, 2013). The congregation of buyer activity data from cookie-based browsing data and server log files data has enabled marketers to provide more specific and additional customized messages than ever before. (Trusov, Ma and Jamal, 2016). From the information provided, the recommendation algorithms will produce performance marketing that provides 
product recommendations to customers after they have browsed or returned to the company's website (Lambrecht \& Tucker, 2013).

Edwards (2015) states that customers are presently turning into oriented with targeted advertisements and have a bearing on expecting to envision relevant promoting messages instead of nonspecific irrelevant ads. Likewise, the data concerning users which are accessible contains real-time, demographics, present location, practice attitude, browsing history, preferences, and kind of mobile appliance (Belch and Belch, 2012, p.511), this allows marketers to focus not only on sectors but also on individuals (Yaniv, 2008, p.90).

Well-constructed use of re-targeting drives to enhance promoters decreases the traditional obstacle of advertisers, as demonstrated in a very popular saying, "Half of the money I pay for advertising is wasted; the difficulty is I don't recognize that half” by Lord Lever. (Hu 2004). Retargeting can also be used to target consumers who may have initially shown an interest in a product, with advertising content that is highly appropriate for them.

Retargeting is commonly referred to as remarketing, although both are considered to have completely different meanings to some degree. Remarketing could be a lot of standard terms indicating to process wherever data gathered from a client is employed in promoting to them through mail message or e-mail message.

Retargeting could be a contemporary term for online marketing strategies, wherever the clients are labeled with cookies as soon as visiting a web site. Then these cookies can be used for online advertising channels targeting the customer (Lambrecht \& Tucker 2013).

\subsection{Consumer Buying Decision Process}

Every company faces challenges in understanding the consumer buying decision process. By the time the corporation's managers know that they can appreciate every customer, there will be modification within the method and its analysis via the customers. There are circumstances in which the corporation affected by unpredicted reactions from the customers, every positive and negative response to the commodity being launched, or the marketing activity being carried out. With so, a lot of researchers attempted to be aware of consumer buying decision behavior.

The classical consumer decision-making model "Five-stage customer buying process model" (Figure 2) contains five steps buyers pass through when purchasing products or services. A seller should realize these stages to properly interchange the buyer to shopping the merchandise, successfully communicatte with customers, and close the sale.

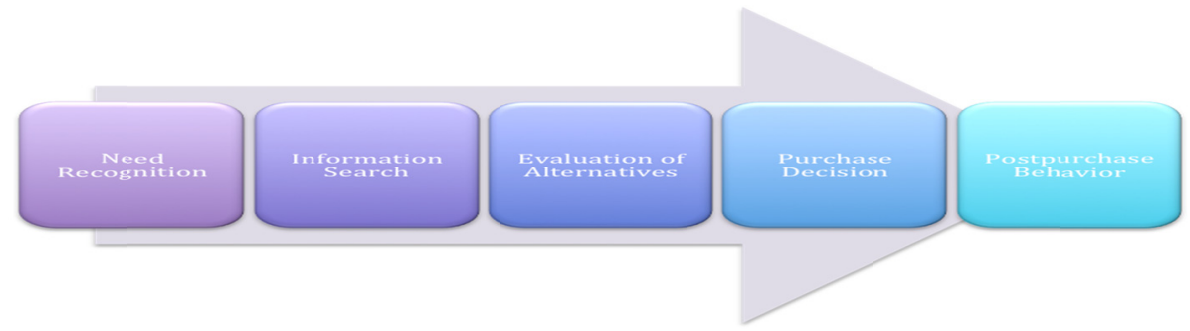

Figure 2. Five-stages model of the consumer buying decision process (Kotler \& Keller, 2012)

Kotler \& Keller (2012) discussed this concept in-depth in their book and outlined the model's other steps-the the process of disposal stage. They also addressed, for example, moderating impact on consumer decision-making (involvement of consumers).

\subsubsection{Need Recognition}

In the beginning, a client can determine the need or the problem. This identification is because of a demand that arises as a result of the modification in the way of living, necessity, or a replacement scenario. This need is separated into two main classes; physical and psychological needs (Michael, 2006). In line with Maslow (1954), Personal needs are classified into needs of social, esteem, physiological, safety, and personal self-actualization. The researchers and theorists regularly accepted this separation of needs. As a consequence of the preceding need, the client will also determine the need and can never be completely satisfied.

\subsubsection{Information Search}

Upon clearly identifying the need, a customer might begin to look for the key to satisfy or adequately address the need. Consumers could trust both external and internal sources within the process. The primary and principal basis is that the knowledge a customer has previously experienced. Unless that knowledge is not sufficient and if 
there are any differences in the way by which the need is identified, or the problem is resolved, the customer might look for external sources of information to be acquired; An additional search for information may be chosen by the consumer on the basis of the value and significance of the product for consumption. It also indicates that, if the importance of the commodity is low and is not essential to its existence, the customer may restrict the quest to the previous experience. (Oliver et al., 2011)

The consumer looks for information that won't only provide options out there for solving the problem, however additionally can offer extra insights concerning the product, alternative out there, entirely different alternatives available for purchase, and an important reason to decide on the purchase of the selected product. Data is offered at the fingertips of the customers in this digital world. (Punj \& Moore, 2009)

\subsubsection{Evaluation of Alternatives}

The information collected by customers from entirely different platforms was assessed for the appropriateness of the need. Defined alternatives have been evaluated with all advantages and disadvantages and with entirely different assessment standards by adding different decision-making principles. While assessing alternatives, the consumer can identify the pre-existing requirements that have been established from previous experience; such parameters may be divided into attributes of hard products and characteristics of soft products (Hallaq and Pettit, 1983).

The firm's hard qualities are the tangible benefits that the consumer can take into account, such as the quality, efficiency, and characteristics of the product. While soft product characteristics are intangible advantages such as appearance, taste, reputation, and brand recognition. Ha (2010) States in his study that the analytical technique itself could get complicated. This could be due to the insufficient time and resources to be used in the analytical procedure.

\subsubsection{Decision Implementation or Purchase}

Customers can quickly get extensive information online before getting their purchase decisions. They can access suppliers worldwide and also have current real market prices (Palos-Sanchez \& Saura, 2018). After assessing the alternatives to choose from depending on the selected criteria, the buyer may choose one product for which to shop. This might just be the customer buying decision process stage where the real transaction happens. Inman et al. (2002) Stated that while making a decided purchase deal for the product, the consumer might end up creating some unplanned purchases. Such unexpected transactions are the result of tempting deals, or merely attributable to the buyer's features. Hoyer and Macinnis (2008), Notice that although the purchaser might have been carefully through all the steps, the buying decision often depends on the accessibility of the influence of the stock and store management.

\subsubsection{Post-Purchase Evaluation}

The purchase made is sufficient or not, depending on whether or not the needs have been satisfied. If the requirement has been fulfilled or the problem has been solved, then there is a chance that the customer will be able to suggest the product to others, and the next time consumers will buy the same product. Making the consumer satisfied is the goal of any corporation, by which brand loyalty is achieved. When the product has met the need, the consumer won't give much importance to the post-purchase evaluation. Furthermore, the buying assessment will not be done entirely unless the consumer is a leader in thinking. The corporations are satisfied with the consumer's purchasing of the product; they will not add much value to the post-purchase assessment. The corporations can neglect that this evaluation by the customer is going to be the foremost vital factor for future purchases or references. Ofir (2005) emphasized the importance of this phase for the next transaction of the purchaser and how the corporations ignore it. Besides, the influence of the reference groups may play a significant role throughout this stage of the post-purchase assessment, not only concerning the consumer.

Increased use of digital marketing as a technology for sales in digital environments has led to a series of research findings in the first decade of the twenty-first century,' Marketing Communication and the World Wide Web' initiated a scientific study of such technologies and web sales. (Saura, Palos-Sánchez, \& Cerdá Suárez, 2017). The effect of digital marketing on the decision-making process for customers in the Egyptian market is the focus of this study. Various studies have been done in regards to digital marketing and how they affect consumer decisions. However, it is apparent from the literature review that, due to the rise of Internet user involvement, actions and decision-making have shifted. Organizations, therefore, need to consider these changes and adapt their marketing activities in different markets appropriately. Organizations, therefore, need to review these changes and adjust their marketing activities in various markets appropriately.; the gap in the identified problem and the previous researches has done, has led the study to formulate the following research question: 
What is the impact of Digital Marketing Channels on Consumer buying Decision process in the Egyptian market?

\section{Research Problem}

Human interactions have been modified considerably as a result of the engagement on social networks; the ascent of net platforms has expedited behavioral changes associated with activities, habitats, and interactions. Customer behavior changes need organizations to re-strategize their marketing activities within the digital space (Tiago \& Verissimo, 2014), so organizations should perceive, however, digital and social media marketing impacts the consumers' buying decision processes (Powers, Advincula, Austin, Graiko, \& Snyder, 2012).

With the increase in social media, marketing departments currently have a wide range of options on the market for branding their product, such as advertising, brand-name business enterprise content, social network contribution, and rising customer engagement prospects to engage with the brand. (Ashley \& Tuten, 2015). Apps or material for digital marketing are most often built to communicate with the user at any time and anywhere, with the intention of informing, engaging, entertaining, or offering feedback for the product (Stone \& Woodcock, 2013).

Customers make purchase decisions every day, and many variables affect any decision made by the buyer. Various applications of the internet, social networks, smartphone apps, and other digital communication tools have turned out to be part of the daily life of many users around the world. Customers are becoming more involved in the creation of the product and services they purchase, and that has changed the control from manufacturer to customer. Web users are significantly rising due to better access to mobile devices, which indeed occupies a majority of their time (Ryan, 2014).

This study explains the value of the digital marketing platforms selected. (E-mail Marketing, Mobile Marketing, and Retargeting) for marketers, and analyzes the impact of these channels on the consumer buying decision process in the Egyptian market.

\section{Research Objective}

This research aims to examine the effect of digital marketing on customer buying decision processes in the Egyptian marketplace. The research study will focus on three of the digital marketing channels (E-mail marketing, Mobile marketing, and re-targeting) Closing the gap in the restricted research carried out on the effect of these platforms on the purchase decision-making process in the Egyptian market

\section{Research Hypotheses}

The following hypotheses were developed and derived from the above literature and theoretical review:

H0: There is no positive impact of Digital marketing Channels on the Consumer buying Decision process.

H01: There is no positive impact of E-mail Marketing on the Consumer buying Decision process.

H02: There is no positive impact of Mobile Marketing on the Consumer buying Decision process.

H03: There is no positive impact of Retargeting on the Consumer buying Decision process.

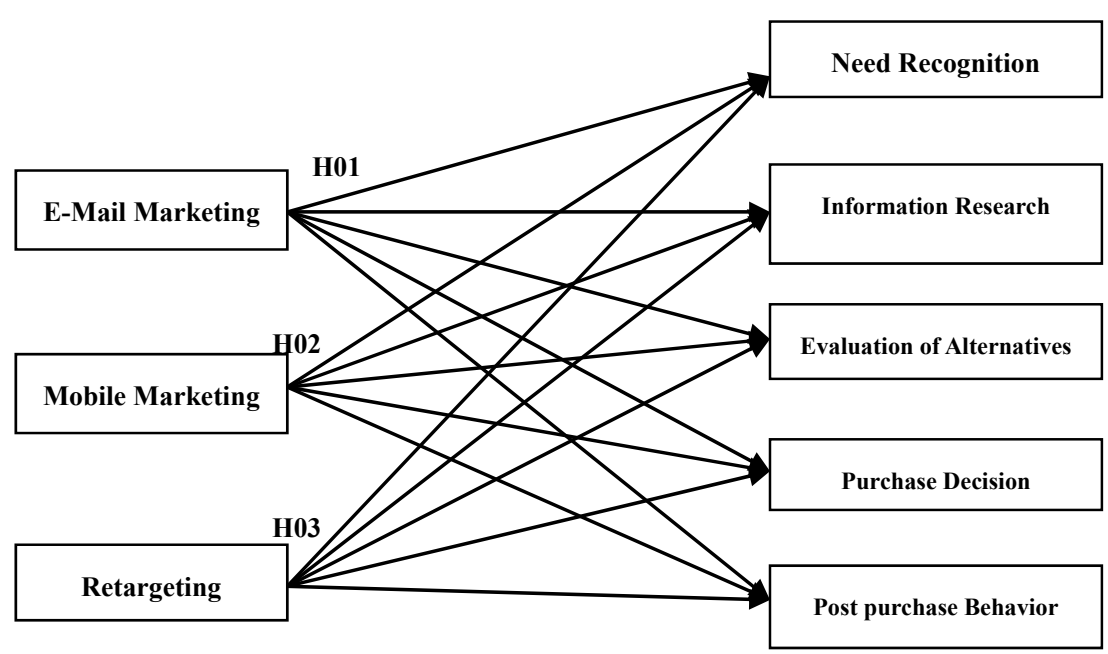

Figure 3. Research model 


\section{Research Scope}

The scope of the study remains within the Egyptian market, with the focus being on the internet users' segment.

\section{Statistical Analysis}

\subsection{Data Collection}

The questionnaires were administered based on a standard sampling method, and 285 questionnaires were distributed in the Egyptian market, and 213 available samples were obtained, except missing questionnaires, producing a response rate of $75 \%$ among those who have decided to participate.

\subsection{Statistical Analysis Methodology}

SPSS software V. 23 was used to analyze the data, and to get the descriptive statistics, Cronbach's $\alpha$ used to test the strength of internal consistency reliability and correlation coefficients. Moreover, AMOS software V. 23 was used to conduct the structural equation modeling (SEM). AMOS is designed to estimate and test SEM. SEM is a statistical model of linear relations between latent (unobserved) variables and manifest (observed) variables. The aim is to approximate the coefficients in a series of structured equations. For this study, AMOS is used to analyze the correlation, where the route coefficients are checked in relevance and goodness-of-fit. The cumulative model fit tests were used to assess the fitness of the structural model. The goodness-of-fit indices that used for measurement and structural models are $\chi^{2}$ test, normed $\chi^{2}$, Goodness of Fit Index (GFI), Normed Fit Index (NFI), Comparative Fit Index (CFI), and Root Mean Square Error of Approximation (RMSEA). The standardized estimates were used in reporting the causal relationships between the exogenous and endogenous constructs.

\subsection{Data Analysis and Results}

\subsubsection{Sample Profile}

Out of a total sample of 213 people who responded, $69.5 \%$ were female, and $30.5 \%$ were male. A wide majority of respondents were between 41 and 50 years of age (34.7\%) and between 21 and 30 years of age (26.3\%). And $43.2 \%$ of our sample used online shopping occasionally; however, $16.9 \%$ rarely used it. Descriptive statistics are displayed in Table 1.

Table 1. Descriptive statistics of the respondents' demographic characteristics (Frequency tables)

\begin{tabular}{llll}
\hline Variable & Frequency & $\mathbf{\%}$ & Cumulative \% \\
\hline I. Gender & & & \\
Female & 148 & 69.5 & 69.5 \\
Male & 65 & 30.5 & 100.0 \\
I. Age $\quad$ & & \\
Below 20 years old & 24 & 11.3 & 11.3 \\
$21-30$ years old & 56 & 26.3 & 37.6 \\
$31-40$ years old & 43 & 20.2 & 57.7 \\
$41-50$ years old & 74 & 34.7 & 92.5 \\
More than 50 years old. & 16 & 7.5 & 100.0 \\
I. Online shopping & & & \\
Rarely & 36 & 16.9 & 16.9 \\
Occasionally & 92 & 43.2 & 60.1 \\
Often & 58 & 27.2 & 87.3 \\
Frequently & 27 & 12.7 & 100.0 \\
\hline
\end{tabular}

\subsubsection{Measurement Model}

Our sample is sufficiently large (213 cases), over the recommended size of 200 cases (Medsker et al., 1994), the scale of observed variables is continuous, and no violations of multivariate normality are found in the survey responses.

The proposed structural model was estimated by SEM, which included a test of the overall model fit and individual tests of the significance of the relationships among the variables. These tests indicated the relationship between the picked digital marketing channels (e-mail marketing, mobile marketing, and re-targeting) for 
marketers and the impact of these channels on the consumer buying decision process. We used the maximum likelihood (ML) method to estimate the model parameters and the overall fit index of the measurement model. The basic assumptions of the ML method (Byrne, 2001\& El-Sheikh et al., 2017) are met or closely approximated in our study.

Confirmatory factor analysis was used to assess the convergent and discriminant validity of the eight variables. Table 2 presents the reliability of the measurement items that were verified using Cronbach's $\alpha$ to assess the internal consistency of the constructs in the model. The level of internal consistency for each construct was acceptable that exceeded the minimum hurdle of 0.50 (Hair et al., 1998). After several trials using modification indices, 16 items were included in our analysis, and the other items (less than 0.5) were deleted. All measurement items had standardized loading estimates higher than 0.5 (ranging from .530to 1.074), indicating the convergent validity of the measurement model. Also, construct reliability (C.R.) was verified to estimate convergent validity; each construct had acceptable construct reliability, because all three constructs to exceed the minimum criterion of 0.5 (ranging from.632to .894) (Hair et al., 1998). Moreover, because the average variance extracted (AVE) from all three constructs exceeded the minimum criterion of 0.5 (ranging from 0.501 to 0.815 ), convergent validity was assured (Hair et al., 1998).

Table 2. Properties of measures (convergent validity and reliability)

\begin{tabular}{|c|c|c|c|c|c|c|}
\hline Construct & $\begin{array}{l}\text { Standardized } \\
\text { loading }\end{array}$ & Mean & SD & $\begin{array}{l}\text { Cronbach's } \\
\alpha\end{array}$ & AVE & $\mathbf{C R}$ \\
\hline E-mail & & 3.641 & 1.155 & .825 & .670 & .802 \\
\hline $\begin{array}{l}\text { E-Mail marketing has played an important role in changing your attitude } \\
\text { toward products and services. }\end{array}$ & .846 & & & & & \\
\hline $\begin{array}{l}\text { E-Mail marketing plays an active role in building a relationship between } \\
\text { the consumers and the organization }\end{array}$ & .790 & & & & & \\
\hline Mobile & & 3.782 & 0.915 & .840 & .710 & .830 \\
\hline $\begin{array}{l}\text { You show a great deal of interests in messages disclosing discounts and } \\
\text { special offers }\end{array}$ & .857 & & & & & \\
\hline Price offers via Mobile marketing are clear and affordable & .828 & & & & & \\
\hline Re-targeting & & 3.624 & 0.902 & .694 & .501 & .632 \\
\hline $\begin{array}{l}\text { It is a pleasure when websites send messages with your name in different } \\
\text { platforms }\end{array}$ & .659 & & & & & \\
\hline $\begin{array}{l}\text { Overall, receiving new offers and promotions about the website which } \\
\text { you visit often makes you stay connected to the website }\end{array}$ & .700 & & & & & \\
\hline Need Recognition & & 3.249 & 0.977 & .601 & .503 & .634 \\
\hline I buy only when it's really necessary & .628 & & & & & \\
\hline I buy the product(s) when it is available at the lowest price & .733 & & & & & \\
\hline Information Research & & 3.944 & 1.142 & .846 & .656 & .785 \\
\hline $\begin{array}{l}\text { I would use digital marketing channels to know more about different } \\
\text { brand/s available }\end{array}$ & .628 & & & & & \\
\hline $\begin{array}{l}\text { I would go through various websites and/or stores to gather more } \\
\text { information about the product(s) }\end{array}$ & .958 & & & & & \\
\hline Evaluation & & 4.169 & 0.817 & .646 & .578 & .718 \\
\hline $\begin{array}{l}\text { I give more importance to consumers feedback while evaluating the } \\
\text { alternatives }\end{array}$ & .936 & & & & & \\
\hline I give more importance for the quality of the product/service offered & .530 & & & & & \\
\hline Purchase Decision & & 3.793 & 0.894 & .811 & .815 & .894 \\
\hline I would prefer doing an online purchase rather than going to the outlet & 1.074 & & & & & \\
\hline $\begin{array}{l}\text { I would prefer to buy from a store where I may get better offers, like free } \\
\text { home delivery }\end{array}$ & .691 & & & & & \\
\hline Post purchase & & 3.951 & 0.903 & .737 & .638 & .773 \\
\hline Shopping online is too time consuming & .638 & & & & & \\
\hline $\begin{array}{l}\text { I would compare the performance of the product(s) with that of the } \\
\text { promise made by the website }\end{array}$ & .932 & & & & & \\
\hline
\end{tabular}

Note. C.R., construct reliability; AVE, average variance extracted. Cronbach's $\alpha$ of all constructs is .881 
For testing the discriminate validity among the constructs, we estimated the correlations among the constructs to determine whether they were significantly different from 1; the confidence intervals of the correlations, calculated as (correlations estimate $+1.96 \times$ standard error of estimate), did not contain 1 , so these results indicated the discriminate validity of the measurement model. Table 3 shows the correlations of the constructs. Overall, these measurement results are satisfactory and suggest that it is appropriate to proceed with the evaluation of the structural model.

Table 3. Correlation matrix and the discriminant validity

\begin{tabular}{|c|c|c|c|c|c|c|c|c|}
\hline & E-Mail & Mobile & Re-targeting & $\begin{array}{l}\text { Need } \\
\text { Recognition }\end{array}$ & $\begin{array}{l}\text { Information } \\
\text { Research }\end{array}$ & Evaluation & $\begin{array}{l}\text { Purchase } \\
\text { Decision }\end{array}$ & $\begin{array}{l}\text { Post } \\
\text { purchase }\end{array}$ \\
\hline E-Mail & 1 & $.287^{* *}$ & $.330^{* *}$ & $.215^{* *}$ & $.543^{* *}$ & $.375^{* *}$ & $.161^{*}$ & $.525^{* *}$ \\
\hline Mobile & & 1 & $.700^{* *}$ & $-.146^{*}$ & $.364^{* *}$ & $.184^{* *}$ & $.243^{* *}$ & $.312^{* *}$ \\
\hline Re-targeting & & & 1 & $.191^{* *}$ & $.397^{* *}$ & $.383^{* *}$ & $.563^{* *}$ & $.390^{* *}$ \\
\hline Need & & & & 1 & $.395^{* *}$ & $.643^{* *}$ & $.281^{* *}$ & $.392^{* *}$ \\
\hline \multicolumn{9}{|l|}{ Recognition } \\
\hline Information & & & & & 1 & $.759^{* *}$ & .076 & $.827^{* *}$ \\
\hline \multicolumn{9}{|l|}{ Research } \\
\hline Evaluation & & & & & & 1 & $.169^{*}$ & $.723^{* *}$ \\
\hline Purchase & & & & & & & 1 & .133 \\
\hline \multicolumn{9}{|l|}{ Decision } \\
\hline $\begin{array}{l}\text { Post } \\
\text { purchase }\end{array}$ & & & & & & & & 1 \\
\hline
\end{tabular}

Figure 4 shows the standardized path regression coefficients that indicate the direct influences of the predictor upon the predicted latent constructs for the research model. Table 4 presents the model fit indices of the structural model and the cut-off value of those fit indices. The goodness-of-fit statistics show that the structural model fits the data reasonably well, and the structural model was a reasonable fit.

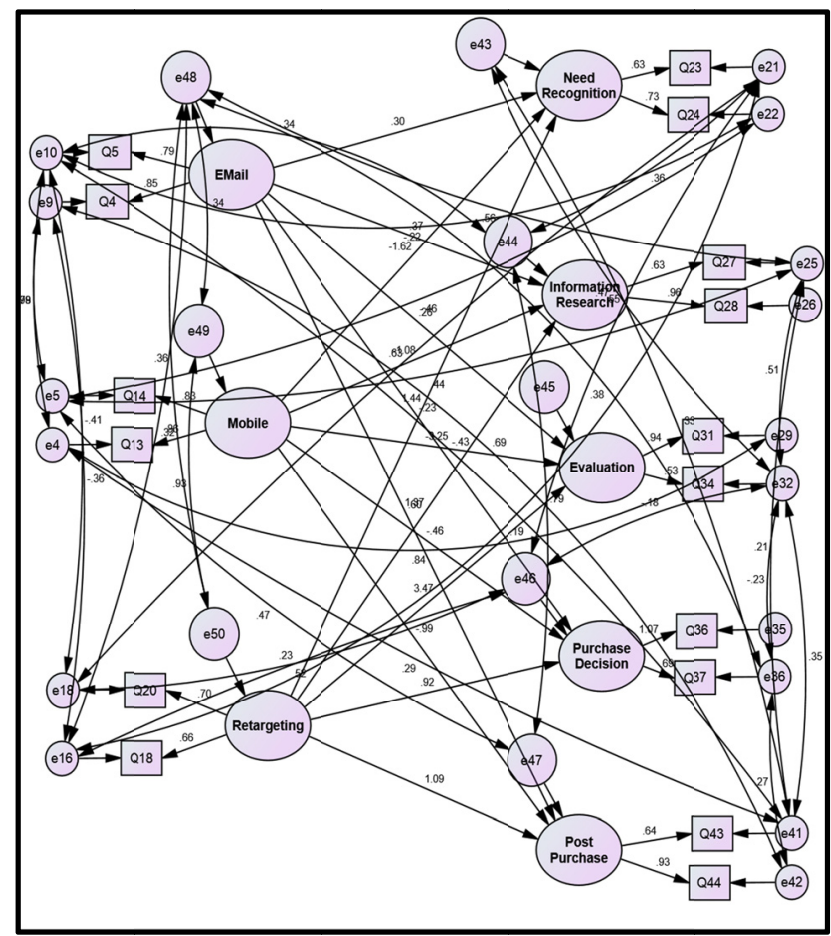

Figure 4. (Structural model) Standardized regression coefficients of the proposed model 
Table 4. Model fit statistics

\begin{tabular}{lll}
\hline Structural model & Fit statistics & Cut-off value \\
\hline$\chi^{2}$ & 108.733 & ----- \\
Normed $\chi^{2}$ & 1.977 & $<3.00$ \\
Goodness of Fit Index (GFI) & .943 & $>0.90$ \\
Normed Fit Index (NFI) & .962 & $>0.90$ \\
Comparative Fit Index (CFI) & .981 & $>0.90$ \\
Root Mean Square Error of Approximation (RMSEA) & .068 & $<0.09$ \\
\hline
\end{tabular}

Table 5. Maximum likelihood estimates for research model $(n=213)$

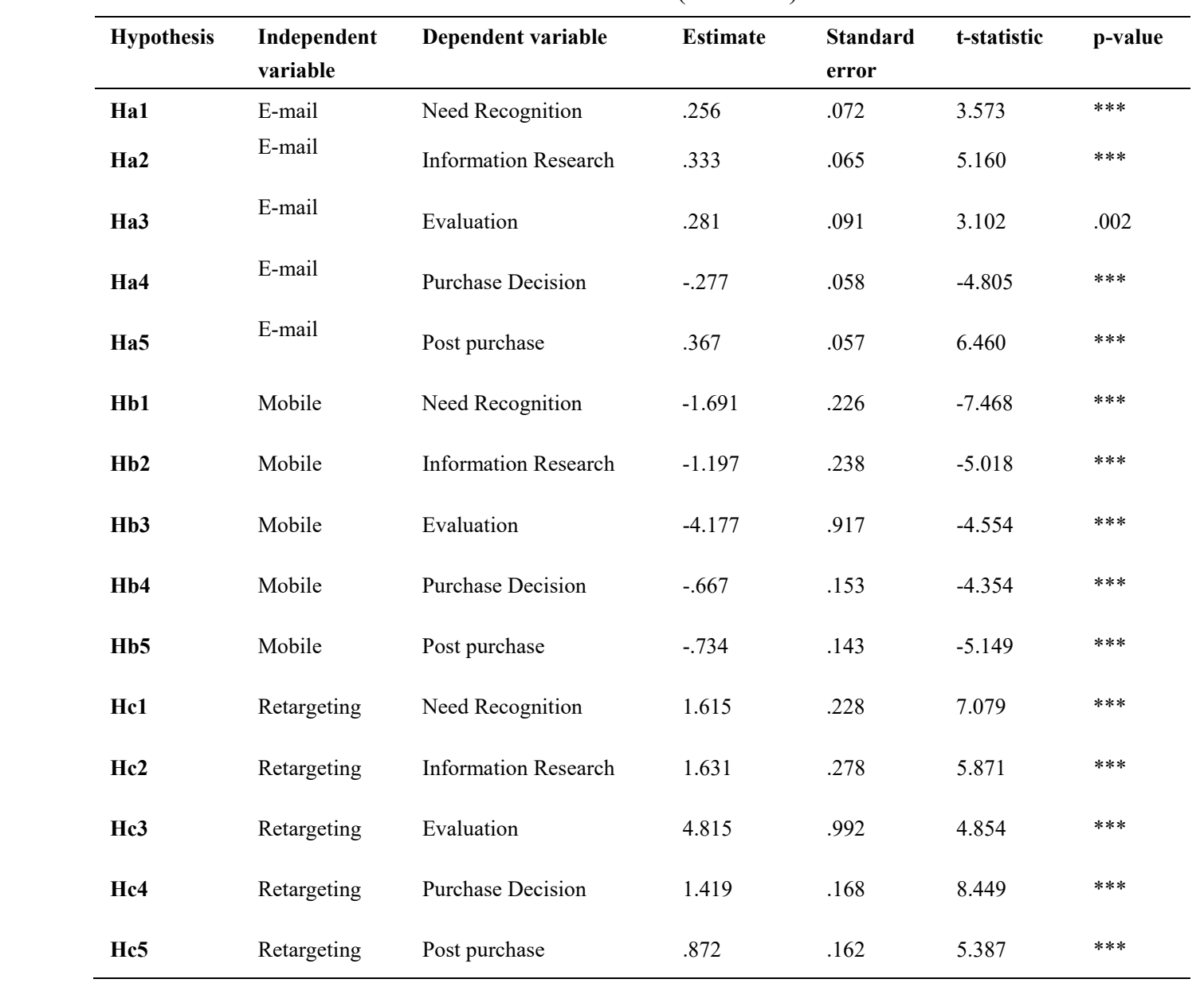

Notes. ${ }^{* * *}$ significant at the $\mathrm{p}<0.001$ level (two-tailed).

Table 5 presents the results of the individual tests of the significance of the relationship among the variables. Among the relationships tested, we found that all relationships are significant at a significant level of 0.01 .

\section{Conclusion and Implications}

This research examines digital marketing channels (E-mail Marketing, Mobile Marketing, and Retargeting) for marketers. It analyzes the impact of these channels on the consumer buying decision process in the Egyptian market.

The author conducted research through an online questionnaire. The questionnaires were distributed based on a simple sampling method and collected in the Egyptian market. 285 questionnaires were distributed and 213 usable samples that were obtained after excluding the incomplete questionnaires, yielding a $74.7 \%$ response rate from those who agreed to participate.

In conclusion, we were able to verify the three hypotheses in the Egyptian market; our findings indicate that 
e-mail has a high positive impact on consumer decisions in two stages (post-purchase and information research), and has a negative impact on consumer decisions in the purchase decision stage.

The results indicate that the mobile as a digital marketing channel has a negative impact on the consumer buying decision through all the stages of the consumer buying decision process. Also, re-targeting has a high impact on consumer decisions in the evaluation stage; then, information research needs recognition, purchase decision, and post-purchase.

Among the three digital marketing channels which represent the independent variables in this research, targeting is the most influential variable on the consumer buying decision process. And we can notice that the strongest effect on the consumer decision is in the evaluation stage, and this can be due to that the re-targeting channel directed to the consumer that is already searching for the product. This consumer already knows the product and is searching for more information to evaluate the product and its different alternatives to complete the stages of the buying decision process. In addition, mobile as a channel of digital marketing is the least influential variable on the consumer buying decision process as the results indicate that it has a negative impact on the buyer decision.

\section{Implications for Marketing Managers}

Marketing managers have to perceive the buyer profile of digital customers and the way their behavior has changed. Those customers have numerous sets of attributes, and their customer behavior has changed to include digital. The post-purchase decision - will change the business to transform a client into a devoted client and turn to be loyal to the brand. Customer service here plays a crucial role. Marketing managers have to be compelled to initiate methods to retain clients by resolve customer complaints.

The last recommendation to marketing managers is that the progressing method of consumer deciding. Because of the digital atmosphere, customers will create a decision to buy a product before a stop at the seller. Thus the in-store impact on a customer to buy becomes the least possible. In essence, businesses have got to create methods to succeed in intent on customers at the moments that the majority influence their choices.

\section{Future Research Recommendations}

Future researches may be performed, taking into consideration the extra factors in digital marketing and different channels. It may be contrasted to the results of this analysis study to identify any variations. Future analysis may be accomplished on entirely different industries within the various markets, and specific organizations and customers.

\section{References}

Ashley, C., \& Tuten, T. (2015). Creative strategies in social media marketing: An exploratory study of branded social content and consumer engagement. Psychology \& Marketing, 32(1), 15-27. https://doi.org/10.1002/mar.20761

Bakshi, G., \& Dr. Surender Kumar Gupta, 2. (2015). Impact of Online and Conventional Advertisement on Consumer Buying Behaviour of Branded Garments. Asian Journal of Management Sciences \& Education, $125-135$.

Belch, G., \& Belch, M. (2012). Advertising and promotion: An Integrated Marketing Communications Perspective. New York: McGraw-Hill/Irwin.

Byrne, B. M. (2001). Structural Equation Modeling with AMOS: Basic Concepts, Applications, and Programming, Lawrence Erlbaum Associates, Mahwah, NJ.

Dickinger, A., Haghirian, P., Murphy, J., \& Scharl, A. (2004). An investigation and conceptual model of SMS marketing. Proceedings of the 37th Annual Hawaii International Conference on System Sciences. IEEE. https://doi.org/10.1109/HICSS.2004.1265096

Edwards, J. (2015). Getting to know you. n.z. Marketing Magazine.

Elisabeta Ioanăs, I. S. (2014). Social Media and its Impact on Consumers Behavior. International Journal of Economic Practices and Theories, 295-303.

El-Sheikh, A. A., Abonazel, M. R., \& Gamil, N. (2017). A Review of Software Packages for Structural Equation Modeling: A Comparative Study. Applied Mathematics and Physics, 5(3), 85-94.

García, J., Lizcano, D., Ramos, C., \& Matos, N. (2019). Digital Marketing Actions That Achieve a Better Attraction and Loyalty of Users: An Analytical Study. Future Internet. Retrieved from http://www.mdpi.com/journal/futureinternet 
Ha, J. (2010). Perceived values, satisfaction, and behavioral intentions: The role of familiarity in Korean restaurants. International Journal of Hospitality Management, 29(1), 2-13. https://doi.org/10.1016/j.ijhm.2009.03.009

Haghirian, P., Madlberger, M., \& Tanuskova, A. (2005). Increasing advertising value of mobile marketing - An empirical study of antecedents. Proceedings of the 38th Annual Hawaii International Conference on System Sciences (pp. 32-32). IEEE. https://doi.org/10.1109/HICSS.2005.311

Hair, J. F., Anderson, R. E., Tatham, R. L., \& Black, W. C. (1998). Multivariate Data Analysis (5th ed.). Prentice Hall, Upper Saddle River, NJ.

Hallaq, J., \& Pettit, K. (1983). The relationship of product type, perceived evaluative criteria, and the order of consumption of the evaluation of consumer products. Advances in Consumer Research, 600-604.

Howard. (2011). Impact of the Internet on Marketing Strategy Formulation. International Journal of Business and Social Science, 1-7.

Hoyer, W. D., \& MacInnis D. H. (2008). Consumer Behavior (5th ed.). South-Western, Mason, OH: Cengage Learning.

Hu, Y. (2004). Performance-based pricing models in online advertising. Available at SSRN 501082, (March). Retrieved from http://scholar.google.com/scholar?hl=en\&btnG=Search\&q=intitle:No+Title\#0. https://doi.org/10.2139/ssrn.501082

Inman, J. J., Winer, R. S., \& Ferraro, R. (2009), The interplay among category characteristics, customer characteristics, and customer activities on in-store decision making. Journal of Marketing, 73(5), 19-29. https://doi.org/10.1509/jmkg.73.5.19

Davis, J. A. (2010). Competitive Success, How Branding Adds Value. United Kingdom: John Wiley and Sons.

Fusion, J. (2011). The Disadvantages of E-mail Marketing, and Access. Retrieved from http://www.superhostingdeals.com/the-disadvantages-of-email-marke ting-1445.html

Jobber, D., \& Ellis-Chadwick, F. (2013). Principles and practice of marketing (7th ed.). McGraw-Hill Education.

Kaplan, A. M. (2012). If you love something, let it go mobile: Mobile marketing and mobile social media $4 \times 4$. Business Horizons, 55(2), 129-139. https://doi.org/10.1016/j.bushor.2011.10.009

Kotler, P., \& Keller, K. L. (2012). Marketing Management (14th ed.).

Krishnamurthy, K., \& Sin, E. A. (2014). Social Media and its Impact on Consumers Behavior. International Journal of Economic Practices and Theories, 295-303.

Lambrecht, A., \&Tucker, C. (2013). When Does Retargeting Work? Information Specificity in Online Advertising. Journal of Marketing Research, 50(5), 561-576. https://doi.org/10.1509/jmr.11.0503

Li, H., Xhang, S., \& Wang, X. (2013). A Personalization Recommendation Algorithm for E-Commerce. Journal of Software, 8(1), 176-183. https://doi.org/10.4304/jsw.8.1.176-183

Maslow, A. H. (1954). Motivation and Personality. New York: Harper.

Medsker, G. J., Williams, L. J., \& Holahan, P. J. (1994). A review of current practices for evaluating causal models in organizational behavior and human resources management research. Journal of Management, 20, 439-64. https://doi.org/10.1177/014920639402000207

Michael, S. (2006). Consumer Behavior - A European Perspective. U.S.: Financial Times, Prentice-Hall.

Mobile Marketing Association. (2009). MMA Updates Definition of Mobile Marketing. Retrieved 27.6.2013 from http://www.mmaglobal.com/news/mma-updates-definition-mobile-marketing

Ofir, C., \& Simonson, I. (2005). The Effect of Stating Expectations on Customer Satisfaction and Shopping Experience, Stanford, Graduate School of Business. https://doi.org/10.2139/ssrn.678382

Oliver, H., Volschenk, J., \& Smit, E. (2011). Residential consumers in the Cape Peninsula's willingness to pay for premium-priced green electricity. Energy Policy, 39, 544-550. https://doi.org/10.1016/j.enpol.2010.10.012

Palos-Sanchez, P., \& Saura, J. R. (2018). The E ect of Internet Searches on A orestation: The Case of a Green Search Engine. Forests, 9, 51. https://doi.org/10.3390/f9020051

Powers, T., Advincula, D., Austin, M. S., Graiko, S., \& Snyder, J. (2012). Digital and social media in the purchase decision process. Journal of Advertising Research, 52(4), 479-489. 
https://doi.org/10.2501/JAR-52-4-479-489

Punj, G., \& Moore, R. (2009). Information search and consideration set formation in a web-based store environment. Journal of Business Research, 62(6), 644-650. https://doi.org/10.1016/j.jbusres.2007.04.013

Ryan, D. (2014). Understanding digital marketing: marketing strategies for engaging the digital generation (3rd ed.).

Saura, J. R., Palos-Sánchez, P., \& Cerdá Suárez, L. M. (2017). Understanding the Digital Marketing Environment with KPIs and Web Analytics. Future Internet, 9, 76. https://doi.org/10.3390/fi9040076

Jenkins, S. (2009). The Truth about Email Marketing. USA: F.T. Press.

VanBoskrik, S., Overby, C. S., \& Takvorian, S. (2011). US Interactive Marketing Forecast. Retrieved from http://www.forrester.com/rb/Research/us interactive marketing forecast\%2C 2011 to 2016/q/id/59379/t/ 2

Scharl, A., Dickinger, A., \& Murphy, J. (2005). Diffusion and success factors of mobile marketing. Electronic Commerce Research and Applications, 4(2), 159-173.

Stone, M., \& Woodcock, N. (2013). Social intelligence in customer engagement. Journal of Strategic Marketing, 21(5), 394-401. https://doi.org/10.1080/0965254X.2013.801613

Tiago, M. T. P. M. B., \& Veríssimo, J. M. C. (2014). Digital marketing and social media: Why bother? Business Horizons, 57(6), 703-708. https://doi.org/10.1016/j.bushor.2014.07.002

Tode, C. (2013). Is mobile a more important ad medium than T.V.? Facebook thinks so. Retrieved from http://www.mobilemarketer.com/cms/news/advertising/15174.html

Trusov, M., Ma, L., \& Jamal, Z. (2016). Crumbs of the Cookie: User Profiling in Customer-Base Analysis and Behavioral Targeting. Marketing Science, 35(3), 405-426. https://doi.org/10.1287/mksc.2015.0956

Ververidis, C., \& Polyzos, G. C. (2002). Mobile marketing using a location-based service. Proceedings of the First International Conference on Mobile Business. Prentice-Hall.

Yaniv, G. (2008). Sold on mobile marketing: effective wireless carrier mobile advertising and how to make it even more so. International Journal of Mobile Marketing, 3(2) 86-91.

Zabadi, A. M. A., Shura, M., \& Elsayed, E. A. (2012). Consumer Attitudes to-ward SMS Advertising among Jordanian Users. International Journal of Marketing Studies, 4, 77-94. https://doi.org/10.5539/ijms.v4n1p77

\section{Copyrights}

Copyright for this article is retained by the author(s), with first publication rights granted to the journal.

This is an open-access article distributed under the terms and conditions of the Creative Commons Attribution license (http://creativecommons.org/licenses/by/4.0/). 